\title{
The Education of Social Assistants in Portugal: Trends in Critical thinking
}

\author{
Cláudia Mônica dos Santos
}

Federal University at Juiz de Fora (UFJF)

\author{
Alcina Maria de Castro Martins \\ Instituto Superior Miguel Torga (ISMT)
}

\section{The Education of Social Workers in Portugal: Critical trends in question}

Abstract: The purpose of this article is to highlight critical influences on professional education in the twenty-first century, in Portugal. It contextualizes social work by highlighting critical inheritances in the education of social workers. It then looks at critical trends in the current education of social workers. It finds that so-called Critical Social Work encompasses different and diverging trends, which are quite diluted in Portugal, expressed by a limited number of professors and individualized methods.

Keywords: Social Work. Professional education. Critical trends. 


\section{Introduction}

Critical analysis has been present in Portuguese social service since the democratization process of the 1970s. According to Martins (2003, p. 2), even in times of the dictatorship in Portugal "there were social assistants who expressed other forms of conceiving and conducting and positioning themselves", countering the conservative legacy of social service. In the 1970s, more precisely with the legislative elections of 1973, there was an outbreak of social movements that had repercussions in social service, more radicalized positions appeared, with participation in union and interunion actions, and social assistants identified themselves as unorthodox and critical. At the time, social service was questioning its conservative legacy in various parts of the world. In Latin America, with the reconceptualization movement, in Canada and in some European countries with critical and radical social service. These are movements that have called for and are still calling for a critical rethinking of traditional social service and reality, through a rethinking of the profession based on various theoretical, ethical-political and technical-operative foundations, which are often divergent and found in various political and economic situations.

Considering this situation, this article has two parts. The first contextualizes social service in Portugal, highlighting critical line of thinking in the education of social assistants. The second part analyzes the development of the so-called critical social service in the current education of social assistants. ${ }^{1}$

\section{Critical education in social service in Portugal: historic contextualization}

The institutionalization of social service as a profession in Portugal dates back to the same period as in Brazil. The first school of social service in Portugal, created in 1935, was the Instituto de Serviço Social de Lisboa [The Institute of Social Service of Lisbon] (ISSL), and was later called the Instituto Superior de Serviço Social de Lisboa [ The Higher Insitute of Social Serice of Lisbon] (ISSSL). In 1937 the Escola Normal Social de Coimbra was created which in 1965, became the Instituto de Serviço Social de Coimbra, and in 1969 the Instituto Superior de Serviço Social and is now known as the Instituto Superior Miguel Torga (ISMT). In Brazil, the first school was created in 1936, at the Pontific Catholic University of São Paulo (PUC/SP). In both countries this professional education had a Christian, Catholic and French-Belgium influence. ${ }^{2}$ Despite some similarities, the development of social service in Portugal took trajectories particular to its economic, political and social conjunctures.

The creation of the first schools of social service in Portugal, in 1935 and 1937, and the creation of the third school, in 1956, the Instituto de Serviço Social do Porto (ISSP), which is now the Instituto Superior de Serviço Social do Porto (ISSSP), took place during the Salazar dictatorship, which was only defeated in 1974. Of the 81 years that social service has been taught in Portugal, 39 were under a fascist dictatorship. These were the only three schools until the 1990s, when, with the fall of the dictatorship, in the revolutionary process sparked by the military uprising of April 25, 1974, ${ }^{3}$ a new political-economic moment began. According to Netto (1986, p. 23), the military dictatorship "was the political solution that the large landowners and capitalists found to respond to the combativeness of the popular organizations and restructure the economy to their benefit", but without the "active consensus of the mass of the population". During the Salazar dictatorship, cultural traditions, moral values and political principles were not emphasized as a strategy for education of future citizens. The regime sought to instill a totalizing concept of the world that "required and created a device for authoritarian, statist, ideological inculcation, which plunged into the daily lives of people (at the level of families, schools, work and leisure), to create this particular 'new man' of Salazarism" (ROSAS, 2001, p. 1031). The social service profession fit into this purpose, that is, of strengthening the dictatorship's motto of God, Fatherland and Family. This is well illustrated in the affirmation of Deputy Antônio Pinheiro Torres about social service: "There is no better propaganda than that which is done so that the wretched feel supported by those who govern". Since the "highest concept of the New State is strengthening the family", social assistants have as their main objective to "spread the doctrine among humble families who are without culture and easily influenced" (TORRES apud MARTINS, 2010, p. 189). In this direction, in 1939, the schools of social service were made official, with explicit educational principals and study plans and programs approved for the purpose of educating "qualified and responsible leaders in their field, who are also active and conscious supporters of the National Revolution" (MARTINS, 2010, p. 134).

The regime began to show signs of decline in the early 1960s. The colonial war $^{5}$ and the economic crisis contributed to this. There were two political cycles in the decline of the Salazar dictatorship. The first ran from the Opposition Uprisings in 1958 to the removal of Salazar from power in 1968. The second includes the rise to power of Marcelo Caetano. As Netto (1986, p. 39) affirmed, the substitution of Salazar by Marcelo Caetano helped maintain the fascist regime considering the economic, political and social conditions that announced its decline: 
This crisis would be led to a conclusion by the political struggle undertaken by the democratic and popular movements, which regained forces between 1968 and 1969, and mobilized with greater vigor. The urban working class (...) and the rural workers (...) would continue to support the resistance, but other protagonists entered the scene. Among them should be highlighted the new middle classes: with their civil service jobs, union actions would spread to spheres until then hostile to organized pressure (particularly categories linked to services). The university and youth movement, in turn, mainly resisting the convocation to military service and to war overseas, would gain a new dynamic. And intellectuals would forge new instruments for confronting the regime (like the Portuguese Writers Association).

It was in this period of the decline of the military dictatorship - from the early 1960s, until approximately 1976 - with the intensification of the popular struggles and the Revolution of April 1974, that Portuguese social service began to adopt critical thinking. According to Martins $(2010 ; 2003)$, this was a project of resistance to the dictatorship and to traditional social service, which was expressed in the development of professionals through strategies to strengthen and organize the populations to support improved living conditions. Inspired by Brazilian educator Paulo Freire, they also participated in adult literacy and consciousness raising programs, triggering a debate about national questions, associated to a critical perspective of the country's situation. This project for the profession also involved the participation of social assistants in the union movement, which became a field of political struggle for union freedoms, where social assistants developed complicities with the struggles of other workers. In this way they ended their isolation and overcame fear, expressing solidarity and demanding justice for social assistants who were arrested, persecuted and targets of repression.

In 1973, for the first time, two competing slates disputed leadership of the union of social assistants. The winner was that defended by the vanguard that distanced itself from the idea that its legitimacy came from the Salazar dictatorship, and affirmed that social assistants should consciously and actively cooperate with the revolution in Portugal. They questioned the idea that social service should remain neutral, as was promoted by the dominant orientations of a U.S. and positivist influence. Social service began to be understood as a profession, and began to approximate currents of critical thinking, whether through dialog between Christianity and Marxism, or through the pedagogy of Paulo Freire. This period was highlighted by strong influence from the first productions of the movement of Reconceptualization of Latin American Social Work, mainly in Argentina, Chile, Brazil and Uruguay.

The influence of Latin American Reconceptualization, according to Martins (2010), contributed to the approximation of Portuguese social service to the Marxist tradition. The social service projects at Latin American schools, such as the Escola de Valparaíso, the Universidade Católica and the Universidade de Concepción in Chile, as well as the so-called BH Method, from the Catholic University of Belo Horizonte, Brazil, became strong references in the education of Portuguese social assistants. Yet the same mistakes were made as those made by the Reconceptualization movement in Latin America, which was to conduct Marxist analysis without access to Marx. ${ }^{6}$ These influences would also lead to changes in nomenclature used by the profession. In the molds of the Latin American countries - with the exception of Brazil - the profession began to be referred to as social work, although the denomination social service returned later. In the words of Negreiros (1999, p. 137), education in social work is based the "on the theoretical body of the social sciences and on the practice of the process of transformation of Portuguese society, envisioned in the intransigent defense of the historic interests of the working class". Professional education was reconsidered at encounters among the three existing schools of social service in the country until 1979 (ISSSL, ISSS of Coimbra and ISSSP). These encounters promoted collective analysis, discussion and re-elaboration of the curricular plans considering the new theoretical-ideological situation. In this period, Brazilian professor José Paulo Netto sought exile in Portugal, and made a strong contribution, broadly promoting the Latin American Reconceptualization Movement at encounters associated to the formation and strengthening of the Association of Social Service Professionals (APSS) and its journal Cadernos. ${ }^{7}$

Between 1974 and 1989, accompanying the country's secularization process, the institutes of social service sought integration to the public universities. In a demonstration in front of the Ministry, in 1975 - which mobilized professors, students, and employees of three institutes and social workers from the union - they chanted "integration or death" and "down with social service at the service of capital" (NEGREIROS, 1999, p. $138 ; 187)$. It was recognized that this process, "in the context of political transformations underway, allowed advances in awareness at the schools and a clarification of their role in overcoming the conditions and forms of exploitation and oppression inherent to the current situation of Portuguese society". The creation of schools of social service at public universities only became definitive in the twenty-first century. ${ }^{8}$

The Revolution of Carnations in 1974 was followed by a counter-revolution by conservative and reactionary forces, and by July and August of 1975 the conquests of the revolution became vulnerable. According to Netto (1986), in the second half of 1976 a political inflection to the right began to be felt, which although irregular, was uninterrupted. This regression was also felt in the profession. In the late 1970s, until the mid 1980s, there was 
opposition to a critical project in social service. This period was marked by the event Portugal hoje, que Serviço Social? [Portugal Today, What Social Service] promoted by Caritas, in 1979. Conservative thinking was revived and confronted the thinking influenced by the Reconceptualization Movement, rejecting Marxism and party militancy. This social service of a modernizing perspective rejected the proposals of Latin American social service, which sought a break with conservative ideas. The Professional Association for Social Service (APSS) was encouraged to strengthen the profession through the creation of a theoretical model and a reformulation of techniques and processes that support interdisciplinarity "understood as the starting and ending point for social service" (Caritas, 1979, p. 9).

Portugal's insertion in the European Economic Community (EEC) in 1986, now the European Union (EU), had implications for education in social service. Iin this decade The Institute of Social Service of Lisbon established an agreement with the Pontific Catholic University of São Paulo (PUC/SP), Brazil, so that Portuguese professors and social assistants could enter its master's and doctoral programs. This partnership helped promote the critical line of social service, with a Marxist inspiration, which had begun in the 1960s and 1970s, with the presence of some Brazilian professors such as Carmelita Yazbek and José Paulo Netto. This contributed to increased reading of Brazilian authors, including Marilda Vilela Iamamoto and Vicente de Paula Faleiros. Nevertheless, Anglo-Saxon influence gained strength, with the neoliberal wave in Europe and the crisis of capital that intensified in the first decade of the twenty-first century.

The 1980s brought great conquests in education, such as the passage of the accreditation programs from four to five years and the recognition in 1989 of the academic degree of accreditation in social service by the Portuguese Ministry of Education.

In 1995, after the return of the first masters in social service from the Pontific Catholic University of São Paulo, Portugal's first master's course in social service was recognized and in 2003 the first doctoral program. In 2000, the first social service course was launched at a public university. ${ }^{9}$ In a period of ten years, the number of schools offering accreditation in social service in Portugal rose from three to $22 .{ }^{10}$ It was in this period that the professional category began to debate the creation of the Order of Social Assistants (OAS), ${ }_{11}^{11}$ "to construct the professional project based on previously undertaken struggles" (MARTINS; TOMÉ, 2016, p. 335).

In 1999, Portugal became a cosignatory of the Bologna Declaration. The adaptation to the Bologna process, the dismantling of the social state and the austerity policies triggered by the capitalist crisis led to deteriorating living and working conditions of the population, affecting the education and work of social assistants. The Bologna process established the demand that by 2010 degrees and diplomas would be harmonized to facilitate the equivalency of university education in the 45 signatory European states, introducing the study cycles: 1st cycle (accreditation/bachelor's), 2nd cycle (master's), 3rd cycle (doctorate), under a concept of continuity and devaluation of education. In this direction, the first and second cycles had to total five years of study. The courses had the flexibility to opt for three years in the accreditation program and two in the master's or three and a half years in accreditation and one and a half in the master's program. That is, the five years of accreditation were transformed into a combined accreditation and master's program, speeding up education, which became fundamentally focused on meeting the needs of the market and not the population. There were no national norms for regulating education, no minimum curriculum and not even general guidelines for the profession - education in Portugal was guided by the Bologna declaration. This situation reflects the absence of entities to organize the professional category, both in the realm of education and in the realm of professional exercise, such as an association for teaching and research and a professional order. Following the European model of course evaluations, Portugal has an Agency of Evaluation and Accreditation of Higher Education (A3ES), which is a private foundation that operates independently within the principles established by the state. Its purpose is to guarantee the quality of higher education through the evaluation and accreditation of institutions of higher education and their study cycles and confirm that their performance is in keeping with Portugal's insertion in the European system of higher education. The external evaluation commission for education in social service, created in 2011, applied criteria established by the Agency of Evaluation and Accreditation of Higher Education to improve the quality of institutes of higher education and their study cycles and offer official recognition, independently of the areas of education and training.

The crises of capital, which became aggravated in 2008 , and the austerity measures implemented in Portugal in 2011, significantly reduced the scope of the social state, leading to impoverishment and growing social inequalities, with flagrant consequences for the education and practice of social workers. In terms of professional practice, social services were privatized, limiting public social services. Civil society organizations began to employ social assistants. Professional practices changed, creating greater dependence on the employer, and now focused on control and monitoring of the population, reinforcing work conducted in offices. Unemployment, and a labor market made extremely precarious by low salaries and a lack of guaranteed labor rights, impeded the insertion and maintenance of the population in higher education (both public and private). 
The 22 existing schools of social work in 2006 were reduced by 2016 to 17 . Among those that were terminated were the courses at the private polytechnic institutes. ${ }^{12}$ This reduction is explained by the increased monthly fees, and because of the "reduction in the provision of study grants, students are forced to abandon the course in the first year, to take out bank loans, including those that have grants, with some becoming indebted" (MARTINS; TOMÉ, 2016, p. 345), and by the lack of adaptation of some schools to the criteria demanded by the evaluation commission.

\section{Critical trend in the education of social assistants in Portugal today}

In 2015 we identified 17 universities or institutes that offered accreditation ( $1^{\text {st }}$ cycle) in social service, six with a master's program ( $2^{\text {nd }}$ cycle $)$ and four with a master's and doctoral cycle $\left(2^{\text {nd }}\right.$ and $3^{\text {rd }}$ cycles $)$. Of the 17 accreditation programs, seven are at private universities, five at public universities and five at public polytechnic institutes. Of this group of schools in social service in Portugal, our study focused on interviewing professors and or coordinators at eight schools and two representatives of professional entities. ${ }^{13} \mathrm{~A}$ total of 10 professors were interviewed. ${ }^{14}$

We also analyzed the study programs in the first cycle of the eight schools where we conducted interviews. Many of the sites studied were not up-to-date or were updated after the period we studied - June to September 2015 - which was compensated for by data from the interviews. In addition to research on the sites, we conducted a bibliographic study of authors identified with critical or radical social service.

The criteria for the choice of accreditation courses were to include: the first schools created in Portugal and still existing until the time of the study; schools whose professors participated in the master's and or doctoral programs at the Pontifical Catholic University in São Paulo, (PUC/SP); schools at private universities, public universities and at public polytechnic institutes in different regions of Portugal: North, Center, Alentejo and Alto Douro. Of the eight schools studied, two were created during the dictatorship and six since the 1990s. Four offer accreditation in three years and the other four in three and a half years. Their curriculums include courses in the following fields: sociology, psychology; anthropology, economics, law, political science, ethics, deontology and social service. In most of the accreditation programs, there are curricular components in all of these fields. The number of curricular components of the various fields varies with the interest of the accreditation programs.

All of the accreditation programs have internships accompanied by academic and field supervisors, although the field supervisors - who are called internship supervisors - do not have to be social service professionals. There is the suggestion that the supervision preferentially be offered by a professional in social service, but this is not mandatory. After the conclusion of the internship activities, a final internship report is required, equivalent to the Final Course Project (TCC) in Brazil.

Research in social service is conducted at five of the accreditation programs, although all of them offer courses in research methodology. The professors express resentment about the low investments in research in social service in Portugal and mention the pressing need for social service to have a culture of research. The graduate programs, which are recent in the country, should contribute to developing this culture in the medium term. Extension activities were not mentioned in the interviews or on the sites of the schools. This can be explained by the fact that extension programs are not mandatory elements of the policies of Portuguese institutions of higher education.

To understand the current situation of critical lines of thinking in professional education of Portuguese social assistants, the study was based on two questions: 1) does social service and accreditation courses in Portugal have a hegemonic theoretical-political direction? If so, what is this direction? 2) What do they consider to be critical and radical thinking? Is this content worked with at their school?

In relation to the first question, some of those interviewed affirmed that it is very difficult to say that education in Portugal has a defined theoretical direction, which is collectively constructed and hegemonic. Those interviewed do not believe that the schools have an affinity to a particular perspective, but that influences from certain historic periods, currents of thinking and orientations are felt in different social projects. Those interviewed also emphasized that this does not mean that on an individual level professors do not have theoreticalpolitical lines with which they have an affinity, but there is no open debate about these lines of thinking, with no movement in one direction or another.

Some of those interviewed believe that there is, in Portugal, a project of education and this is based on the systemic (S) line of thinking and its derivations. They understand that, even if unconsciously, this is the line that is most present in Portuguese social service. Three people interviewed also believe that in their schools, the systemic direction is the strongest, although they coexist with professors with different theoretical-political concepts. "The systemic is perhaps the most organized in Portugal, but there is no systemic movement, individually, 
there are many people affected, influenced either by some generations, or by a relationship with psychology and family therapy" (Interview, June 2015).

Some professors affirm that the fragile organization of the professional category in Portugal makes a more collective movement around a professional project more difficult. The $1^{\text {st }}$ cycle schools are isolated from each other and each has its own curriculum. The lack of a basic curriculum or curricular guidelines also contributes to this isolation. This is combined with a professional culture that has emphasized eclecticism in education and professional practice. The eclecticism is accepted as something positive by some professors and treated as synonymous with democratization of education and pluralism by others. Some even understand that they have a critical analysis of reality, but a functionalist practice. On the other hand, they understand that the accreditation programs should respect all the various contributions without imposing a single line or direction. A direct relationship is seen between the theoretical direction of each school and a limitation of the autonomy of professors. There is no open discussion about pluralism and eclecticism. These affirmations point to the existence of an educational project, however, it is not systematized, it is not debated, and therefore it is not clearly assumed by the category as a project. The situation may express the lack of a strong theoretical foundation or the lack of theoretical clarity and command of different lines of thinking, which is also expressed in the critical line of social service.

In response to the second question, about critical and radical social service, the majority of those interviewed responded that these tendencies do not currently have considerable expression in Portugal, although they affirm that students are educated to develop critical thinking and in this sense "even Marx" (Interview in June 2015) is presented, but in a course about the history of social service. That is, the critical and radical lines are approaches presented in the schools, but "not in the sense of saying that this is the line of thinking but in the perspective of saying that we as professionals can only act in this way: we must defend the rights of the population, involve the population in the recognition of their rights" (Interview held in May 20152015). They reaffirm that this line was more prominent in the 1970s and in the mid 1980s. Meanwhile, some of those interviewed confirm that radical and critical social service are lines that are worked with in the schools and there are professors who, individually, and in isolation work in this direction.

Questioned about what they consider as the critical line in social service, they point in different directions that involve emphasizing: a sense of defense of rights; support for the population; participation, empowerment; antioppressive social service; feminist social service; Marx; or the direction of Brazilian social service. In reality, they

The professors unanimously recognize that critical social service, of a Marxist orientation, had strong influence in Portugal only in the 1970s and with a strong influence from the Pontifica Catholic University of São Paulo, Brazil (PUC/SP), at the time of the creation of masters and doctoral programs in the mid 1980s and 90s. understand that in Portugal there is a critical cultural and political melting pot in education about social service, but it is limited to a criticism of neoliberal regimes, and attacks on the state of law, while demanding a social state.

An analysis at the schools revealed various curriculum components that address critical and radical social service. The curriculums include the following courses: methodology of social service, theories and models of social service and models of intervention. The courses in theories and models include the contents: general systems theory, ecological systems theory, psychosocial theories and radical and Marxist theory. In the courses on intervention models, the contents vary around: systemic models, both ecological and in network; psychosocial models; constructivist models; structural models and critical social service.

The content of critical social service includes various components: feminist intervention; critical-dialectical social service; anti-discriminatory and anti-oppressive practices and empowerment. The content of radical and Marxist theory includes: radical social service, anti-discriminatory and anti-oppressive theory, critical theory, reflexive theory and cognitive and behavioral theories. These contents and the statements from the interviews reveal the complexity of the issue. Although the theoretical perspective tends more closely to a systemic conception, it was found that on a smaller scale critical social theory is presented until today in professional education in Portugal. This content appears in the study plans of courses in the historiography of the profession, particularly by presenting the reconceptualization movement in Latin America - a content that is offered in 
practically $99 \%$ of the eight schools studied - and also in components of theory, methodology and models of social service. The study also shows that the denomination critical social service involves different understandings and theoretical orientations.

In a first analysis, the study identified three trends in the critical line in social service. One is guided and supported by historical-dialectical materialism. As a Marxist social theory, it understands that poverty and labor exploitation are inherent to capitalism, and therefore capitalism cannot be humanized. The second trend, known as critical and radical social service, also criticizes capitalism, but focuses on neoliberalism, seeks improvements in social welfare systems and criticizes various forms of oppression. This tendency includes: anti-oppressive social service, feminist social service, anti-racist social service and even some concepts of empowerment that are based on Paulo Freire and phenomenology. The third line is based on the theory of correlation of forces, which focuses on individuals and not on problems "understanding that the particularities of each case involve aspects of the general situation. In this complex relationship of the structure with the individual, an important maxim is that of the radicalness of the criticism and of the realism of the action" (AMARO, 2008, p. 74), with the intention to strengthen and empower identity, autonomy and citizenship. It turns to theoretical support from Vicente de Paula Faleiros, who is inspired by the constructivism of Bourdieu.

These three trends have convergent and divergent aspects. Some common aspects are: criticism of the positivist influence and of the neutrality of social service; recognition and or awareness of the political and ethical dimension of the profession; orientation by principles of justice, democracy, liberty, citizenship and autonomy; a defense of human rights, the elimination of prejudice and discrimination; and a commitment to the population and to social equity.

In terms of divergent aspects we can highlight a number of contrasts: 1) in terms of the long term objectives of the profession: there are differences between an emphasis on human emancipation versus a humanization of capital or a strengthening of individuals for purposes of social transformation; 2) between a perspective of totality over the expressions of the social question or a phenomenic analysis of the expressions of the social question; 3) between various theoretical supports in the analysis of reality, encompassed by Marxian social theory versus Paulo Freire versus the Frankfurt school and post-modern thinkers; 4) a defense of socialism, at its horizon versus a defense of the social welfare state versus resistance to neoliberalism; 5) an emphasis on class conflict, while working with other forms of oppression or an emphasis on various forms of oppression: gender, race, ethnicity, generation and class or an emphasis on individuals and communities; 6) different concepts of the principles of justice, democracy, liberty, citizenship, autonomy, defense of human rights, elimination of prejudice and discrimination, commitment to the population and social equity, considering the different theoretical orientations that support it.

\section{Final considerations}

The professors unanimously recognize that critical social service, of a Marxist orientation, had strong influence in Portugal only in the 1970s and with a strong influence from the Pontifica Catholic University of São Paulo, Brazil (PUC/SP), at the time of the creation of masters and doctoral programs in the mid 1980s and 90s. Today, there are professors who seek Marxist references, although in an individual manner. Most of the professors and professionals who are guided by the so-called critical line work above all in the second and third directions indicated above. A more detailed analysis shows that these two trends, although they are perspectives that counter perspectives of order and regulation, may also express a new conservatism in the profession.

\section{References}

AMARO, M. I. Os Campos paradigmáticos do Serviço Social: proposta para uma categorização das teorias em Presença. Revista Locus Social, Lisboa/Portugal, p. 65-80, 2008.

CARITAS PORTUGUESA. Portugal Hoje, que Serviço Social? Dias de Estudo, 7, 8 e 9 maio e 2,3 e 4 de Julho 1979 (brochura mimeografada).

MARTINS, A. Investigação em Serviço Social: perspectivas actuais. In: HENRÍQUEZ, B. Alfredo; FARINHA, M. A. (Org.), Serviço Social: unidade na diversidade. Encontro com a Identidade Profissional - I Congresso Nacional de Serviço Social, Lisboa, Associação dos Profissionais de Serviço Social, 2003, p. 50-61.

MARTINS, A. Génese, emergência e institucionalização do Serviço Social português. Beja: Encadernação Progresso, 2010.

MARTINS, A; TOMÉ, M. R. Regressividade no Serviço Social português: impactos de Bolonha e da austeridade na formação e no trabalho. In: ALVES, M.; TORRES, L.; DIONÍSIO, B; ABRANTES, P. (Org.) A educação na Europa do Sul. Constrangimentos e 
desafios em tempos incertos. Lisboa: Faculdade de Ciências Sociais e Humanas da Universidade Nova de Lisboa, 2016, pp. 335-356. Disponível em: http://www.aps.pt/index.php?area=302. Acesso em: 22 mar. 2016.

NEGREIROS, M. A. Serviço Social uma profissão em movimento. A dinâmica académico-profissional no Portugal pós-74. Tese doutoramento em Serviço Social apresentada à Pontifícia Universidade Católica de São Paulo, 1999.

NETTO, J. P. Portugal. Do Fascismo à revolução. Porto Alegre: Mercado Aberto. 1986.

ROSAS, F. O Salazarismo e o homem novo: ensaio sobre o Estado Novo e a questão do totalitarismo. Lisboa: Instituto de Ciências Sociais da Universidade de Lisboa, Análise Social, vol. XXXV (157), 2001, p. 1031-1054.

VENTURA, A. Ideologia e Mentalidade do Estado Novo Salazarista. In: CALAFATE. P. História do pensamento filosófico português - O Século XX. Lisboa: Caminho, 2000.,

\section{Notas}

1 This study is part of the post-doctoral research entitled O Serviço Social Crítico em Portugal, o Projeto ético-político no Brasil e o Serviço Social Radical: aproximações possíveis, de 2015, [Critical Social Service in Portugal, the political-ethical project in Brazil and Radical Social Service: possible approximations] from 2015, which focuses on the social service project constructed in Portugal and Brazil beginning with the democratization process of the 1970s and its current consequences for the profession. The study and this article are financed by CAPES/Brasil, process number: 6190-14-6.

2 Portugal had Anglo-Saxon and U.S. influence in the period before the creation of the first school of social service. Meanwhile, "the doctrinaire, religious and corporativist character that the regime would determine for the schools of social service conflicted with these values" (MARTINS, 2010, p. 171), given that social service in England had a scientific basis and no influence from the Catholic Church.

325 April 1974 is the date of Portugal's Revolution of the Carnations, triggered by the population and by the segment of the military known as the Movimento das Forças Armadas. The name comes from the florists at the Rossio Plaza in Lisbon, who greeted the soldiers with red carnations, which became the symbol of the Revolution (NETTO,1986).

4 Rosas (2001) considers that Salazar's fascism sought to construct a particular belief of Portuguese society in the "new man" based on what they denominated the founding ideological myths of the New State: the polygenetic myth, which concerned the myth of re-beginning, of Portuguese Renaissance, of regeneration operated by the New State, which interrupted more than 100 years of national decadence caused by monarchic and then republican liberalism; the myth of the ontological essence of the regime, which evoked the new nationalism; the imperial myth, which revived the Portuguese vocation for colonization and Evangelization; the myth of rurality, which expressed a specific virtue which tempered the social being of Portuguese nationality; the myth of honorable poverty, which exalted decent work and poverty; the myth of corporativist order, which reinforced the idea of a spontaneous and harmoniously established hierarchy in the social world in an a-historic manner; and finally the myth of the Catholic identity of the national essence, in which Catholicism is constituted as an attribute of nationality and of its very history, and therefore of being Portuguese.

5 The Salazar regime maintained colonies in various African territories (Angola, Mozambique, Cape Verde, Guine Bissau and São Tomé and Príncipe) and in Asia (Goa, Damão and Diu - possessions in India, Macao and Timor). The outbreak of the popular revolt in Angola in 1961 had repercussions in other Portuguese colonies in Africa. To contain the rebellions, the fascist Portuguese regime conducted military operations to confront African resistance.

6 According to António Ventura (2000, p. 202), Marxism in Portugal was presented at universities in the first decades of the twentieth century until the end of the New State, "in a summary and schematic manner; accompanied by commentaries and value judgments; without the bibliographies of works of Marx and Engels, who were referred to indirectly or through French translations". The situation changed after 1970, and Marxism became freely promoted by political organizations and universities at colloquiums and recognized as an important current of contemporary thinking.

7 Between 1977 and 1980, APSS edited seven issues of the publication Cadernos. The first issue, September/October 1977, helped to leverage the mobilization of social assistants and the institutionalization of the Association that took place in January 1978.

8 In 1964 the first public school in social service was created in Portugal, at the Instituto Superior de Ciências Sociais e Políticas Ultramarinas (ISCSPU), although it was soon disbanded.

9 It should be recalled that public universities in Portugal are not free of charge, but monthly fees are quite low compared with the private universities.

10 This increase does not take place without problems for education, considering that, according to interviews with professors conducted during our research, public education institutions do not maintain their own faculty in the field of social service or have a structure for research, which is the rule for other fields of knowledge and in this type of education.

11 Equivalent to Brazil's Federal Social Service Council. Until March 2016, Portugal did not attain approval of the OAS, but the APSS continues to struggle for this approval.

12 Polytechnic education is guided by different requirements than university education. For example: it does not have the same tie with research; the length of the accreditation courses in a polytechnic school is three years, while at universities the tendency is for the 1st cycle in social service to have seven semesters.

13 Portugal has an Association of Social Service Professionals] (APSS) and the National Union of Social Assistants. In Europe, a Portuguese social assistant is president of the International Federation of Social Workers (FITS/Europe), Portuguese professors participate in the European 
Association of Social Work Schools (EASSW) and a Portuguese social assistant is a member of the board of the European Association of Research in Social Work (ESWRA), although not as a representative of the country.

14 All are doctors. Of these, eight are doctors in social service, and four have a doctorate and masters through an agreement between ISSSL and the Pontific Catholic University of São Paulo, Brazil (PUC/SP), in the 1990s and early 2000s. At the time of the interview, six professors were coordinators of the accreditation program, two were coordinators of the third cycle; two were retired but teaching in the second and third cycle; and all had scholarly publications in social service.

\section{Cláudia Mônica dos Santos}

cmonicasantos@gmail.com

Doutora em Serviço Social pela Universidade Federal do Rio de Janeiro (UFRJ)

Professora da Faculdade de Serviço Social da Universidade Federal de Juiz de Fora (UFJF)

\section{Alcina Maria de Castro Martins}

alcina_martins@sapo.pt

Doutora em Serviço Social pela PUC/SP.

Professora de Serviço Social do Instituto Superior Miguel Torga (ISMT)

\section{UFJF}

Campus Universitário de Martelos, S/N.

Juiz de Fora - Minas Gerais - Brasil

CEP: 36036-900

\section{ISMT}

Largo de Cruz de Celas, 01

Coimbra - Portugal

CEP: 3000-132 